\title{
Water for Cities in Nigeria: The Governance Dimension
}

\author{
Emmanuel M. Akpabio \\ Lecturer, Department of Geography and regional Planning, \\ University of Uyo, Nigeria. \\ Iniubong E. Ansa (Corresponding Author) \\ PhD candidate, Department of Geography and Regional Planning, \\ University of Uyo, Nigeria. Email:mcansa1@yahoo.com
}

Doi: 10.5901/mjss.2013.v4n4p297

\section{Abstract}

This work assesses the state of water resources in Nigeria in the light of the global state of the affairs of water management. The study takes an in-depth survey of water availability globally on a regional per capita basis. The study further exposes contemporary trends in water management with particular focus on efforts at privatisation. The study goes further to expatiate the concept of water governance with a view to furnishing sound knowledge of the political, economic, social and administrative variables involved before it proceeds to assess the state of the affair in Nigeria, with the Niger Delta in perspective. The study concludes by drawing up the emerging issues in water governance in Nigeria for policy and practice.

Keywords: Water Resources, Governance, Privatisation, Nigeria, Niger Delta

\section{Introduction: General Background and the State of Global Knowledge}

On a global scale and when measured at an aggregate level, there is sufficient water available for everybody's minimum needs. Against estimated annual renewable freshwater supplies of between 9 and 14 trillion cubic meters, current global usage stands at less than 4 trillion cubic meters (Rosegrant, 1997). The major issue is that global availability of water is not matched by adequate local access. Geographically and temporally, freshwater distribution remains surplus for some people and deficit for others. Ayibotele's (1992) projection of regional changes in per capita water supplies since 1950 shows that per capita water supply was in Latin America and lowest in North Africa and North East. Supply in Europe and North America was not expected to change greatly by 2000 due to low population growth rates (Table 1).

Table 1: Water Availability (1000 per capita, per annum) by region

\begin{tabular}{|l|l|l|l|}
\hline Region & 1950 & 1980 & 2000 \\
\hline Africa & 20.6 & 9.4 & 5.1 \\
\hline Asia & 9.6 & 5.1 & 3.3 \\
\cline { 2 - 5 } Latin America & 105.0 & 48.8 & 28.3 \\
\hline Europe & 5.9 & 4.4 & 4.1 \\
\hline North America & 37.2 & 21.3 & 17.5 \\
\hline
\end{tabular}

Source: Ayibotele (1992)

There has also been considerable interest generated on withdrawals of fresh water from rivers, lakes, reservoirs, underground aquifers, and other sources. By Shiklomanov's (1993) estimation, this has increased by more than a factor of four with Asia accounting for the largest share of the developing world's water withdrawals (Table)

Table 2: Per capita Domestic Water Withdrawals, 1995 and 2020

\begin{tabular}{|l|c|c|}
\hline & $1995 \mathrm{~m}^{3}$ per capita/ & $2020 \mathrm{~m}^{3}$ per capita/ \\
\hline Sub-Saharan Africa & 11 & 15 \\
\hline Asia & & 71 \\
\hline China & 25 & 54 \\
\hline India & 20 & \\
\hline \multicolumn{2}{|c|}{} \\
\multicolumn{2}{|c|}{297}
\end{tabular}




\begin{tabular}{|l|c|c|}
\hline Other East Asia & 77 & 98 \\
\hline Other South Asia & 21 & 41 \\
\hline South-East Asia & 56 & 87 \\
\hline Latin America & 65 & 82 \\
\hline West Asia/North Africa & 56 & 70 \\
\hline Europe & & \\
\hline Western Europe & 94 & 94 \\
\hline Eastern Europe \& CIS & 89 & 103 \\
\hline USA & 240 & 240 \\
\hline World & 56 & 75 \\
\hline
\end{tabular}

Source: Webb \& Iskandarani (1998)

These projections imply that by the year 2020 Asia will overtake both Europe and the USA in per capita withdrawals accounting for 60 percent of the world's water withdrawals accounting for 60 percent of the world's water withdrawal. Activities that mostly drive this water demand upward are located in irrigation agriculture and industrial expansion, with India and China leading in the race. Rosegrant et al (1997) noted that demand in China, for example, is expected to triple between 1995 and 2020, while in India an increase of around 270 percent is expected. Using the stress index' (which defines national water stress in terms of internal renewable fresh water availability between 1000-1667 cubic meters per capita per annum and water scarcity in terms of internal renewable fresh water availability lower than 1000 cubic meters per capita per annum), it is estimated that the number of people living in water-scare countries will rise from 132 million in 1990 to 653 million (under the low UN population growth projection) in 2025 (WRI, 1996). By 2050, the figure would rise to between 1 billion and 2.4 billion (depending on the projection variant), representing 13 to 20 percent of the projected global population. It is clear in the reports that certain continents, Africa and parts of Western Asia in particular, are already highly vulnerable to increasing water scarcity.

Taking a critical look of these analyses, Webb \& Iskandarani (1998) have shown that such projections have to be interpreted carefully since they are based on past trends (for water supply) and estimates of future usage based largely on demographic dynamics and which do not incorporate possible changes in water use efficiency. The authors observed that Burundi, for example, is potentially a water-scare country according to the water stress index, but it uses little water for irrigation at present and so has abundant supplies for other purposes (Table 3).

Table 3: Countries Facing Potential Water Insecurity in 2000 According to the Water Stress Index

\begin{tabular}{|l|c|c|c|}
\hline \multirow{2}{*}{ Country } & \multirow{2}{*}{$\begin{array}{c}\text { Population } \\
\text { (millions) }\end{array}$} & $\begin{array}{c}|c| \\
\text { Internal Renewable fresh water } \\
\text { availability (m³ per capita) }\end{array}$ & $\begin{array}{c}\text { Water Resources including river } \\
\text { flows from other countries }\end{array}$ \\
\cline { 3 - 4 } & & 29 & 934 \\
\hline Egypt & 62.4 & 103 & 103 \\
\hline Saudi Arabia & 21.3 & 108 & 108 \\
\hline Libyan A. J & 6.5 & 152 & 152 \\
\hline United A. E & 2.0 & 153 & 240 \\
\hline Jordan & 4.6 & 154 & 155 \\
\hline Mauritania & 2.6 & 155 & 335 \\
\hline Yemen & 16.2 & 260 & 445 \\
\hline Israel & 6.4 & 384 & 2008 \\
\hline Tunisia & 9.8 & 430 & 436 \\
\hline Syrian A. R. & 17.7 & 436 & 487 \\
\hline Kenya & 34.0 & 487 & 576 \\
\hline Burundi & 7.4 & 570 & 11326 \\
\hline Algeria & 33.1 & 591 & 604 \\
\hline Hungary & 10.1 & 604 & 11187 \\
\hline Rwanda & 10.4 & 622 & 760 \\
\hline Botswana & 1.6 & 760 & 880 \\
\hline Malawi & 11.8 & 880 & 3923 \\
\hline Oman & 33.1 & 905 & 943 \\
\hline Sudan & 33.1 & 943 & 1086 \\
\hline Morocco & 31.8 & 1086 & \\
\hline Somalia & 10.6 & & \\
\hline
\end{tabular}

Source: Webb \& Iskandarani (1998) 
N/B: Water Stress: internal renewable fresh water availability between 1,000-1,667 cubic meters/capita/annum, water scarcity: internal renewable fresh water available $<1,000$ cubic meters/capita/annum. A number of other countries with smaller populations, e.g., Barbados, Cape Verde, Djibouti, Malta Qatar and Singapore are also included in the waterscarce category

It is important to note that what amounts to national averages mask diversity at the sub-national level. While scarcity may not always appear at the national level, serious water shortages are apparent in certain regions and watersheds, mostly areas in dry marginal lands, high risk flood or drought areas, fragile watershed hillsides and urban slums. Notable examples include northern China, western and southern India and parts of Mexico. For example, although India as a whole has adequate average water supplies of 2,500 cubic meters per capita, the state of Rajasthan has access to only 550 cubic meters (Rosegrant et al, 1997). Similarly, while China has only 7 percent of the world's renewable freshwater supplies (for 22 percent of the world's population), water stresses are not uniform across the country (Ryan and Flavin, 1995). They are felt acutely in the northern and western arid regions, while the coastal southeast consumes even more water for its industrial and urban development (Smil and Yushi, 1998). Nigeria has often been considered a well-drained country with abundant water resources, yet water availability potential for the south is far greater than north because of high differences in rainfall occurrence between the two regions. Mean annual can be as high as $2250 \mathrm{~mm}$ for Uyo and as low as $750 \mathrm{~mm}$ for Kano. Mean annual water surplus can be as high as 1250 for 125 for Kano while mean annual water deficit could be around 125 for Uyo and 750 for Kano (Ayoade and Oyebande, 1983).

Watersheds located in arid and semi-arid regions are home to more than 1 billion people (Revenga et al. 1998). Countries in these regions have been known to account for 70 percent of the world's poorest people (Broca and Oram, 1991). One of the key factors that have been held as responsible for the poverty of these regions is water insecurity and this manifests through the limits it places on non-farm processing industries, constraints on health and sanitation improvements, and of course constraints on agriculture. Apart from the limited availability of water in the regions, salinity is another significant and widespread form of freshwater pollution in the arid and semi-arid regions and this has been blamed on over-pumping of aquifers, poor drainage and high evaporation rates which concentrates salts on irrigated land, thereby reducing productivity over the longer term.

Flooding and droughts have also been other twin causes of water insecurity world-wide. Between April 1997 and April 1998, floods were reported in over 40 countries, while droughts were a problem for 22 countries (FAO, 1998). These extreme weather anomalies always affect every sphere; submerging productive lands, destroying infrastructures, and killing/displacing humans.

The fragility of watershed poses another problem. According to Revenga et al (1998), 42 of the world's most important 145 watersheds have lost more than 75 percent of their original forest cover and 15 have lost more than 95 percent. Consequently associated soil erosion has been severe in many watersheds, particularly in China, south-east Asia, parts of Central America, Southern Africa and Madagascar, all of which are characterized by fragile highland ecologies.

The next concentration of water insecure people can be found in urban slums. Of the $\$ 134$ billion invested in water supply and sanitation during the 1980 s to 1990 , urban areas are estimated to have received $74 \%$ of the total and rural areas only $26 \%$, despite the fact that it costs an average of $\$ 105$ per capita to provide water supplies in urban areas versus onlyUS $\$ 50$ in rural areas (WHO, 1996). Despite this, statistics show that by 1994, about 30 percent of all urban residents in Sub-Saharan Africa were not served by municipal water services of nay kind (WRI, 1996). In Nigeria, for instance, it is estimated that effective urban water supply coverage may be as low as $30 \%$ of the total population due to poor maintenance and unreliability of supplies (FGN, 2000).

In terms of water quality, there are still 1.2 billion people without safe drinking water and almost 3 billion lacking adequate excreta disposal facilities (WHO, 1997). A recent estimate by the WHO/UNICEF (2000) observed that over 170 million people have no access to clean water in urban areas of Africa, Asia and Latin America. Without access to a minimum of 15 (pastoral) to 20 litres (sedentary) of safe water person per day, a household faces serious water insecurity risks (Teka, 1977; Gleick, 1996). WHO (1996) estimates that 5 million people (all ages) die each year from due to unsafe water and the lack of sanitation. Some water is poisonous or harmful. These may be related to the natural systems or human activities. For instance Ghosh (1998) reported that large numbers of Bangladeshis have recently been affected by water containing high concentration of arsenic, derived from wells sited over geologic deposit of arsenic. Other sources of water are merely harmful because of the numerous wastes and chemical pollution activities of industries (Gupta, 1992).

In general, there are five main categories of diseases related to water: i) water-borne (typhoid, cholera, dysentery, gastro-enteritis and infectious hepatitis); ii) water-washed infections of the skin and eyes (trachoma, scabies, yaws, leprosy, conjunctivitis and ulcers); iii) water-based diseases (schistosomiasis and guinea-worm); iv) diseases from water- 
related insect vectors such as mosquitoes and black flies; and v) infections caused by defective sanitation (hookworm) (WHO, 1998). Unfortunately, there is considerable uncertainty about the relative importance of each of these transmission paths (Kjellen and McGranahan, 1997). Some of these diseases are coming under control, but others remain global scourges. WHO (1995) has observed that diarrhoeal disease liked to unsafe water are responsible for 3 million deaths each year among children under age 5 in the developing countries. Africa has been known to be the worstaffected, with an average diarrhoea-related mortality rate of 17 per 1,000 (Sharma, 1996).

The declining water resource in the world is a great concern for many countries especially for water scarce countries. Rational choices have to be made in the face of competitive water demands. Consequently, policy makers have been forced to categorize water as an economic good that would be subject to the dictates of demand and supply as well as emphasis on demand-oriented management strategy. Concern about the economic management of water as a commodity has led increased attention to water pricing and to markets (Webb \& Iskandarani, 1998). This trend has been accelerated by pressures mounting on governments to withdraw long-stand subsidies, impose fees for water provided, or even to divest themselves of responsibilities for water supply and allocation altogether.

Today, the privatization of water utilities is proceeding in some developing countries, with management of water systems being transferred to private firms, autonomous utilities, and/or water user associations in the hope of improving management, reducing costs and saving water. Water privatization is in much literature considered to be the process where major and often international companies take control over water distribution and sell water to consumers on the basis of market mechanism. This has been in accordance with much of the international political changes over the last decades where international institutions and country donors have promoted structural adjustment policies and liberal economic policies in the developing countries and the former eastern bloc. Focus has been on privatization and market liberalism and has hampered governments in attempts to extends water and sanitation facilities (Thomas \& Clegg, 1998). This is what is often described as the neo-liberal approach. A major challenge with this type of privatization is that it has cost-recovery through user fees implicit and that it often is difficult to see which responsibility that the companies have. In partnership with private companies, many local governments end up as profit seekers and think in terms of market mechanisms and tend to forget about those that cannot afford to pay for basic provision (UN-HABITAT, 2003). The UN report on water and sanitation in the world's cities from 2003, also display another type of water privatization. This is mostly common with small-scale vendors buying or just taking water from municipal pipes before they sell this water to clients in a specific, minor urban areas.

The debate on whether private or public has not been conclusive and none of the argument in the literature conclusively support the claim that the private sector involvement in water resources management would lead to improved result and performance. A general notion in the neo-liberal thinking is that there is a clear relationship between performance and ownership (Schulpen \& Gibbon, 2001). According to Nellis (1994), private ownership will perform better than public ownership because: it establishes a market for managers, leading to higher quality management; capital markets subject private enterprises to greater security; private enterprises are much more subject to exit; politicians interfere less in the affairs of private enterprises than they do for public enterprises; and private firms are supervised by self-interested board members and shareholders, rather than by disinterested bureaucrats. However, in the water sector some studies have proven the contrary to this assumption (Renzetti \& DuPont, 2003). For instance, Brynes et al (1989) undertook a comparative study in the USA and found no difference in efficiency between public and private ownership. In contrast, Lambert et al (1993) also undertook a study in the USA and found publicly owned water utilities to be more efficient. Bhattacharyya et al (1994) also undertook a study in the USA and also found no difference in overall efficiency, but privately owned utilities were found to be technically inefficient. While in the UK, Saal \& Parker (2001) found that privatization increased profits but not productivity. The case is therefore clear that in spite of the drive for privatization in the water sector, its main economic expectation of improved performance is not guaranteed by mere shift of ownership from the public to the private sector. Grosh (1991) carried out a study of public enterprises in Kenya and found scant reason to expect that privatization will yield improvements in either efficiency or profitability.

Generally, literature has recognised some forms of privatization in the water sector to include the following (Hukka \& Katko, 2003):

Full Divestiture: Full transfer of assets to private sector through asset sales, share sales or management buyouts. Private sector is responsible for all capital investment, maintenance, operations and revenue collection;

Partial Divestiture: Government or any public owner sells a proportion of shares in an incorporated enterprise or creates a new joint venture company with the private sector;

Concession: Government lets a long-term contract, usually over 25 years, to a private company, which is responsible for all capital investment, operations and maintenance; 
Lease: Long-term contract (usually 10-20 years but can be longer). Private sector responsible for operations and maintenance and sometimes for asset renewals. Assets remain in public sector and capital investment remains a public responsibility;

BOT (Build-Operate-Transfer)/BOO (Build-Operate-Own): Contracts are issued for the construction of specific items of infrastructure, such as a bulk supply reservoir or treatment plant. Normally, the private sector is responsible for all capital investment and owns assets until transferred to the public sector, but in BOO schemes, private ownership is retained.

Management Contract; Short-term contracts, typically five years. Private firm only responsible for operations and maintenance;

Service Contract (Buying in); Single function contracts to perform a specific service (e.g., install meters) foe a fee.

As way of countering water privatization, proponents of public sector provision see water as a basic need and a service of public interest. This is because water is essential for human life and indeed for all life on earth. In this case water would preferably be left in the public hands in order to ensure public interest although private provision does not necessarily rule out public interest (K' Akumu, 2006). Other arguments have sought to portray water as a public good that must be in the public hands (Budds \& McGranaham, 2003). Many writers also agree that is a natural monopoly because it requires huge capita investments in plant and networks, which should not be left in the hands of the private market (Marvin \& Laurie, 1999; Budds \& McGranahan, 2003). In this case, the argument is that investing in plants and networks in the same geographical region in a competitive manner will tantamount to gross misallocation of resources. The human rights perspective of water has also been used as a case for public provision ( $K^{\prime}$ Akumu, 2006). It is for this reason that international conventions have endorsed water as a human right, which can only be ensured by the state.

Another important contentious issue around water border on water related conflicts at many fronts. The prospect that social and political conflicts over the distribution and allocation of water will increasingly become a key part of the 21 st century landscape is regularly re-echoed by international leaders (Castro, 2007; Van Ginkel, 2001). For instance, in February 2006, the British government issued a dramatic warning about the increased likelihood of "wars over water" and announced that its military forces must be prepared to intervene in "humanitarian disaster relief, peacekeeping and warfare" related to dwindling natural resources, particularly water (Castro cites The Independence, 2006). It is important to understand that the governance of trans-boundary water resources is a major problem. According to the register of international rivers of the now defunct UN Centre of Natural Resources, Energy and Transport, it was estimated in 1977 that there were 214 major shared international freshwater resources 155 of which flow through two countries, and the rest through three or more countries (Finger, et al, 2006). These figures are due for updating since the breakup of the Union of Soviet Socialist Republics and of the Balkan States. For example, a recent World Bank report refers to "over 245 basins", which serve about 40 percent of the world's population and half of its surface. According to other estimations, there are much more. A. group of researchers have updated the UN register to list 261 international rivers, which cover almost half of the land surface of the globe (Finger et al, 2006). L. Milich and R. G. Varady (cited in Finger et al, 2006) put the number of shared river basins at "more than 300". The United Nations Commission on Sustainable Development, in its 1997 Comprehensive Assessment of the Freshwater Resources of the World, also estimated that the number of transboundary river have risen to over 300 . These all point to the fact of serious governance problems coming. However, Castro (2007) has written that this notion that international water wars imminent is fiercely contested by authors who argue that there is scarce historical evidence in favour of the hypothesis that trans-boundary waters tend to be the cause of war between countries and that rather peaceful cooperation in water sharing would have been the main international pattern of millennia (Allan, 2001; Cosgrove 2003 \& Yoffe et al, 2004).

The important lesson about this debate is the fact that it has brought to the front burner the potential sources of water related international conflicts, which are far from being settled. Castro (2007) also observed the second dimension of water related conflicts that continue to receive relatively less attention in the mainstream water policy literature. This is intra-national water conflicts. This characterization, according to the author, may be misleading, as in fact in many cases water conflicts have both an inter-and an intra-national dimension. The important issue here is that this type of conflict border on social struggles over water that range from confrontation over the control of water bodies and water infrastructure to urban conflicts over the inequalities and inefficiencies in the access to essential water services. Historically, the control of water and water systems has played a significant role in the emergence of social and political conflicts. Consequently, scholars have beamed the searchlight on appropriate water management system that will guarantee equitable access while at the same time minimizing incidence of conflicts. Governance has been seen as a possible solution to future water problems. The next section of this paper discusses the concept of water governance as a prelude to seeing how such concept has been working in the water sector in Nigeria. 


\section{The Concept of Governance in the Water Sector}

Governance as a concept has been increasingly applied in the water sector of recent because of its centrality in water management. The works of many scholars such as Kooiman (1993; Rogers and Hall (2003); Frank (2004); Frank and Cleaver (2007 have offered useful direction for discussing water governance as a concept. Rogers and Hall, for instance, defined water governance 'the range of political, social, economic and administrative systems that are in place to develop and manage water resources and the delivery of water services, at different levels of society'. This definition builds on general ideas of governance as comprising a range of systems including those of government and the public services but also extending to services provided by other sections of society. According to Frank (2004, this definition recognizes that these systems related and link to each other through political processes, which are inevitable in the management of any resource such as water. It suggests a range of outcomes (water resources as well as water services) which go far beyond the management functions of individual organizations or groups.

In practical application, water governance is the dynamic functioning of formal and or informal institutions directed at ensuring efficient, accountable and timely delivery of water and water services across all segments of the population, social and economic systems; as well as the general ecological systems. For this type of governance system to be effective in the water sector, Roger and Hall (2003) believe the political elements, which should aim at balancing various interests and facing political elements, which should not be ignored. To ensure that the governance system leads to better economic, social and environmental outcomes for the water sector, some necessary preconditions of inclusiveness, accountability, participation, transparency, predictability and responsiveness must be fulfilled. These are necessary ingredients for good governance. Good governance for the water sector can lead to a better opportunity for efficient and improve service delivery. On the other hand, poor governance would certainly result in increased political and social risk, institutional failure and rigidity and deterioration in the capacity to cope with shared problems (Rogers and Hall, 2003).

As governance has been broadened to cover both the formal and informal institutions at all levels, there also emerge the challenge of reconciling authorities and minimizing authority conflicts at all levels and among various stakeholders. This challenge has led to the emergence of what Finger et al (2006) refers to as multi-level governance. In the context of globalization, the argument here is that governance in the water sector should be driven by stakeholder approach since water and water management cuts across geographical boundaries, ecosystems, social systems and involves all levels of authorities. This emphasis is captured by the Commission on Global Governance (1995) as follows.

Governance is the sum of the many ways individuals and institutions, public and private, manage their common affairs. It is a continuing process through which conflicting or diverse interests may be accommodated and co-operative action may be taken. It includes formal institutions and regimes empowered to enforce compliance, as well as informal arrangement that people and institutions either have agreed to or perceive to be in their interest.

Finger et al (2006) observed that this definition has possibly captured everything, from individuals working together to cooperation among nation-states. The authors, however, observed that this conceptualization of governance mixes together institutions and individuals, and does not account for their relative power, nor for their different strategic interests.

Generally and from the few review, it is very clear that governance is very important and most needed in the water sector to incorporate all real and potential stakeholders at all levels of authorities and across all sectors and issues such as the survival of the ecosystem and climate change, among others. The question here is how does governance system operate in the water sector in Nigeria? The task of this paper is to address this question. To effectively address this question, the next section of this paper will discuss the general sate of Nigeria's water resources.

\section{Nigeria's Water Resources and Use}

Geographically, Nigeria is located in the tropical zone of West Africa between latitudes $4 \mathrm{~N}$ and $14 \mathrm{oN}$ and longitudes $2^{\circ} 2^{\prime} \mathrm{E}$ and 14 일 $\mathrm{E}$ has a total area of 923,770 square kilometres $\left(\mathrm{km}^{2}\right)$. The country's north-south extent is about $1,050 \mathrm{~km}$ and its maximum east-west extent is about $1,150 \mathrm{~km}$. Nigerian is bordered to the west by Benin, to the northwest and north by Niger, to the northeast by Ched and to the east by Cameroon, while the Atlantic Ocean forms the southern limits of Nigerian territory. Land cover ranges from thick mangrove forest and dense rain forests in the south to a neardesert condition in the north-eastern corner of the country.

Three broad ecological zones are commonly distinguished in the country: i) The northern Sudan Savannah; ii) The Guinea Savannah Zone or Middle Belt; and iii) The southern rainforest zone. Based on rainfall and temperature the country is divided into eight agro-ecological zones. These zones are presented in a north-south succession, except the 
mountainous zone which is found at the border with Cameroon and the plateau zone in the centre of the country. The climate is semi-arid in the north and humid in the south. Except for an ultra-humid strip along coast with rainfall averages of over 2,000 millimetres per year (mm/year), where it rains almost all year round, rainfall patterns are marked by distinct wet and dry seasons. Rainfall is concentrated in the period June-September. Deficiency in total annual precipitation is a problem in parts of the country, particularly in the northern parts. In most other areas, however, the major problems are the distribution in time and space and the low dependability of rainfall. Mean annual rainfall over the whole country is estimated at $1,150 \mathrm{~mm}$. It is about $1,000 \mathrm{~mm}$ in the centre of the country and $500 \mathrm{~mm}$ in the northeast. Mean annual evaporation is $2,450 \mathrm{~mm}$ in the southeast, $2,620 \mathrm{~mm}$ in the centre and $5,220, \mathrm{~mm}$ in the north of the country.

The country is well drained with a close network of rivers and streams. Some of these, particularly the smaller ones in the north, are seasonal. There are four principal surface water basins in Nigeria:

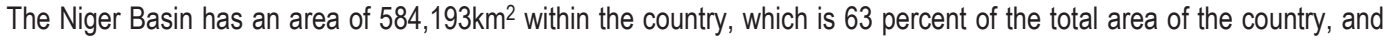
covers a large area in central and north-western Nigeria. The most important rivers in the basin are the Niger and its tributaries Benue, Sokoto, and Kaduna.

- The Lake Chad Basin in the northeast with an area of $179,282 \mathrm{~km}^{2}$, or 20 percent of the total area of the country, is the only internal drainage basin in Nigeria. Important rivers are the Komadougou Yobe and its tributaries Hadejia, Jama' are, and Komadougou Gena.

- The south-western littoral basins have an area of $101,802 \mathrm{~km}^{2}$, which is 11 percent of the total of the country. The rivers originate in the hilly areas to the south and west of the Niger River.

- The south-eastern littoral basins, with the major watercourses being the Cross and Imo Rivers, have an area of $58,493 \mathrm{~km}^{2}$, which is six percent of the total area of the country, and receive much of their runoff from the plateau and mountain areas along the Cameroon border Nigerian has extensive groundwater resources, located in eight recognized hydro geological areas together with local groundwater in shallow alluvial (fadama) aquifers adjacent to major rivers:

- The Sokoto Basin Zone comprises sedimentary rocks in northwest Nigeria. Yields range from below 1.0 to 5.0 litre per second $(\mathrm{L} / \mathrm{s})$.

- The Chad Basin Zone comprises sedimentary rocks. There are three distinct aquifer zones: Upper, Middle, Lower. Borehole yields are about 1.2 to $1.6 \mathrm{~L} / \mathrm{s}$ from the Upper unconfined aquifer and 1.5 to $2.1 \mathrm{~L} / \mathrm{s}$ from the Middle aquifer.

- The Middle Niger Basin Zone comprises sandstone aquifers yielding between 0.7 and $5.0 \mathrm{~L} / \mathrm{s}$ and the Alluvium in the Niger Valley yielding between 7.5 and $37.0 \mathrm{~L} / \mathrm{s}$.

- The Benue Basin Zone is the least exploited basin in Nigeria extending from the Cameroon border to the Niger-Benue confluence. The sandstone aquifers in the area yield between 1.0 and $8.0 \mathrm{~L} / \mathrm{s}$.

- The south-western zone comprises sedimentary rocks bounded in the south by the coastal Alluvium and in the north by the Basement Complex.

- The South-Central Zone is made up of Cretaceous and Tertiary sediments centred on the Niger Delta. Yields are 3.0 to $7.0 \mathrm{~L} / \mathrm{s}$.

- The south-eastern zone comprises Cretaceous sediments in the Anambra and Cross River basins. Borehole numbers are low due to abundant surface water resources.

- The Basement Complex comprises over 60 percent of the country's area. It consists of low permeability rocks and groundwater occurs in the weathered mantle and fracture zones with yields of between 1.0 and $2.0 \mathrm{~L} / \mathrm{s}$.

Lake Chad is an important wetland lying in the semi-arid Sahel corridor with a mean depth of 3.9 meters $(\mathrm{m})$, its surface area is highly variable, ranging from a minimum of $2,000 \mathrm{~km}^{2}$ in 1907 to a maximum of $22,000 \mathrm{~km}^{2}$ in 1961 . Lowlying areas flooded during the wet season, known as fadama areas, are scatted across the ecological zones of Guinea Savannah, Sudan Savannah, and the Sahel. These diverse wetlands are valuable for grazing, agricultural, and other domestic uses, and are deemed of international importance as breeding grounds for migratory birds, thereby having a global value for biodiversity. Nigeria's total annual renewable water resources are estimated at $286.2 \mathrm{~km}^{2}$. Annual internally produced resources amount to 221 cubic kilometres $\left(\mathrm{km}^{2}\right)$, made up of $214 \mathrm{~km}^{2}$ surface water and $87 \mathrm{~km}^{2}$ groundwater, while $80 \mathrm{~km}^{2}$ of the latter is assumed to be overlap between surface water and groundwater. External water resources are estimated at $65.2 \mathrm{~km}^{2} / \mathrm{year}$, being surface water coming from Niger, Cameroon, and Benin. Exploitable surface water resources are estimated to be 80 percent of the natural flow, which is about $96 \mathrm{~km}^{2} / \mathrm{year}$. Annual extractable groundwater resources are about $59.51 \mathrm{~km}^{2}$, distributed as follows: $10.27 \mathrm{~km}^{2}$ in northern Nigeria; $25.48 \mathrm{~km}^{2}$ in the Middle Belt; $23.76 \mathrm{~km}^{2}$ in the south. Dam capacity is estimated to be $44.2 \mathrm{~km}^{2}$. Total annual water withdrawal was estimated at $8 \mathrm{~km}^{2}$ for the year 2000 . Agriculture was the biggest water user with $5.5 \mathrm{~km}^{2}$, or 96 percent of the total water withdrawal, 
followed by the domestic sector with about $1.7 \mathrm{~km}^{2}$ (21 percent) and industry with $0.8 \mathrm{~km}^{2}$ (10 percent). Nigeria is a member of two regional authorities dealing with the management of shared water resources:

- The Niger Basin Authority (NBA) was formed in 1964 and is made up of the nine countries that share the Niger Basin (Guinea, Cote d' Ivoire, Mali, Burkina Faso, Algeria, Benin, Niger, Chad, Cameroon). The principal aim of the authority is to ensure the integrated development of the basin.

- The Lake Ched Basin Commission (LCBC) comprises representatives of Cameroon, Central African Republic, Chad, Niger, and Nigeria. Its objective is to ensure a rational and equitable development of natural resources, including water, of the Lake Ched Region.

In addition, Niger and Nigeria by signing the MAIDUGURI Agreement in 1990 have established a joint commission to monitor and assess development options, particular water resources development, in the four major sub-basins common to the two countries. However, the implementation of the Agreement has been ineffective so far.

\section{Irrigation and Drainage Development}

Irrigation potential estimates in Nigeria vary from 1.5 to 3.2 million ha. The latest estimate gives a total of about 2.1 million ha, of which about 1.6 million are from surface water and 0.5 million ha from groundwater. However, as far as groundwater is concerned, it should be mentioned that while the extractable water resources are sufficient for up to 0.5 million ha in the north of Nigeria, areas suitable for irrigation with groundwater have, as yet, not been assessed. Areas with irrigation potential using surface water are given in Table 4.

Table 4: Irrigation Potential Using Surface Water (ha)

\begin{tabular}{|l|l|l|l|l|l|l|}
\hline Zone & Uplands & River Valleys & Inland Swamps & Delta Swamps & Total & $\%$ \\
\hline North & 343,000 & 578,500 & 154,100 & - & $1,075,600$ & 68 \\
\hline Middle Belt & 82,000 & 28,000 & 28,000 & - & 138,000 & 9 \\
\hline South & 180,000 & 11,000 & 93,400 & 78,000 & 362,400 & 23 \\
\hline Total (ha) & 605,000 & 617,500 & 275,500 & 78.0 & $1,576,000$ & 100 \\
\hline$\%$ & 38 & 39 & 18 & 5 & 1000 & \\
\hline
\end{tabular}

Source: FAO (2009)

During the oil boom of the 1970s, an investment program in support of public irrigation was launched. Public irrigation in the Nigerian context means schemes run either by River Basin Development Authorities (RBDAs) or by the states. The program included the construction of large dams and pumping station, especially in the dried northern part of the country. By 1990, 162 dams had been constructed with a total storage capacity sufficient to irrigate 725,000 ha if developed. Many of these dams, however, were built with little or no infrastructure and the sites chosen do not always have sufficient irrigable areas close by. The schemes that were developed have not been brought into production fully or they have been implemented with inappropriate infrastructure. By 2004, only about 20 percent of the area planned for public sector irrigation had been developed and only 32 percent of the developed area was being irrigated.

The poor utilization of the developed irrigation area in the public irrigation sector can be attributed to a number of factors including: i) the lack of a coherent irrigation subsector development policy and strategy; ii) insufficient attention to management systems; iii) inadequate funding (including poor cost recovery); iv) high capital and operating costs; v) inadequate farm support services; vi) high capital and operating costs; v) inadequate farms support services; vi) poor operation, repair and maintenance; vii) a low level of project ownership acceptance by the direct beneficiaries; and viii) uncertain financial and economic viability. Because of these lapses, a number of schemes have already deteriorated badly and are in urgent need of major renovation and repair, less than 20 years after their construction.

Private sector irrigation in Nigeria is small-scale with the exception of two sugar estates, which operate as private companies but receive government support (but they are almost non-existent at present; for example, of the 7,000 ha equipped for irrigation in Savannah sugar estate only 500 ha were cropped and irrigated in 2004). About two-thirds of the irrigated area of the private sector are small-scale areas of commercial vegetable, horticulture, and flower producing schemes around larger cities. The remaining is classified as fadama irrigation, which resulted from the NFDP (FAO, 2000). 


\section{Water Governance in Nigeria}

Water governance in Nigeria is located at very highly generalized and broad levels. Nigeria's water resources management is anchored dominantly on a federal framework consisting of three tiers namely Federal government, states government and local government. Relevant laws and regulations on water resource use have been found in several documents and instruments (Table 5) as well as customary practices.

Table 5 List of statutes on water resources in Nigeria

\begin{tabular}{|c|c|c|}
\hline S/N & Name of Statutes & Key Provision \\
\hline 1. & The Waterworks Act of 1915 & $\begin{array}{l}\text { Colonial Nigeria (shortly after Amalgamation in 1914) passed the law } \\
\text { specifically to keep water from being polluted. It prohibits the pollution of } \\
\text { water in Nigeria by obnoxious or harmful matters. }\end{array}$ \\
\hline 2. & The Minerals Act of 1917 & $\begin{array}{l}\text { The law vests the Head of State of Nigeria with power to make regulations for } \\
\text { the prevention of pollution of any watercourse }\end{array}$ \\
\hline 3. & The Public Health Act of 1917 & It prohibits the fouling of water and vitiation of the atmosphere \\
\hline 4. & The oil in Navigable Waters Act, 1968 & It prohibits water pollution by oil spillage \\
\hline 5. & The Petroleum Act, 1969 & $\begin{array}{l}\text { It covers prevention of pollution by inland waters, rivers, lakes and } \\
\text { watercourses. }\end{array}$ \\
\hline 6. & The Land Use Act of 1978 & Ownership of Land linked to ownership of groundwater resources. \\
\hline 7. & $\begin{array}{l}\text { The River Basin Development (RBDA) } \\
\text { Decree } 25 \text { of } 1976 \text { (repealed by No. } 87 \\
\text { of } 1979 \text { and also latter by the RBDA } \\
\text { Act, Decree } 35 \text { of } 1987 \text {, i.e. Cap 396) }\end{array}$ & $\begin{array}{l}\text { In its present from Cap } 396 \text { spells out diverse functions and objectives for } \\
\text { these Authorities to ensure a Pan-Nigerian Programme for water resources } \\
\text { development. }\end{array}$ \\
\hline 8. & $\begin{array}{l}\text { The Environmental Impact Assessment } \\
\text { (EIA) Decree, No. } 86 \text { of } 1992\end{array}$ & The law seeks to protect the physical and aquatic environment. \\
\hline 9. & $\begin{array}{l}\text { Water Resources Decree, No.101 of } \\
1993 \text { ) }\end{array}$ & $\begin{array}{l}\text { It vests the right to use and control all surface waters and groundwater and of } \\
\text { all water in any water course affecting more than one state in the Federal } \\
\text { Government, with provisions that any person may take water without charge } \\
\text { for his domestic or livestock watering purposes (in any watercourse to which } \\
\text { the public has free access) }\end{array}$ \\
\hline 10. & $\begin{array}{l}\text { The } 1999 \text { Constitution of the Federal } \\
\text { Republic of Nigeria }\end{array}$ & $\begin{array}{l}\text { The constitution puts in the Exclusive Legislative List (ELL) shipping and } \\
\text { navigation on the River Niger and on any of its affluent and on any such other } \\
\text { inland waterway as may be designated by the National Assembly to be an } \\
\text { international waterway or to be an interstate waterway. The ELL also includes } \\
\text { water from such sources as may be declared by the National Assembly to be } \\
\text { sources affecting more than one state. }\end{array}$ \\
\hline 11. & National Policy on Environment 1989 & Protection of the environment \\
\hline 12. & $\begin{array}{l}\text { National Guidelines and standards for } \\
\text { Environmental pollution control in } \\
\text { Nigeria (1991) }\end{array}$ & Pollution control in watercourse as part of the environment. \\
\hline 13. & $\begin{array}{l}\text { National Effluent Limitation Regulation } \\
1991\end{array}$ & Control of discharge of industrial waste and sewage into watercourses \\
\hline 14. & $\begin{array}{l}\text { Pollution Abatement in Industries and } \\
\text { Facilities Generating WASTES } \\
\text { Regulation } 1991\end{array}$ & Control of industrial pollution \\
\hline 15. & Waste Management Regulation, 1991 & Waste Management \\
\hline
\end{tabular}

Constitutionally, water resource is placed in the concurrent list of the 1999 constitution, involving all tiers of government and private sector. Matters bordering on international water rights and management come under the Exclusive Legislative List (e.g., Nigeria is a signatory to many international regulations and conventions on water). This implies that issues bordering on international waters are strictly on the exclusive domain of the federal government-the basis for which Nigeria maintains peaceful relationship with her riparian neighbours (e.g., Chad and Niger Republics). Article 20 of the 1999 constitution also grants powers to states of the federation as thus: "the State shall protect and improve the environment and safeguard the water, air and land, forest and wild life of Nigeria". Prior to 1999, domestic water management had no position in the political decision making process. There were, however, selected but water 
related legislation at pre-independence, colonial (e.g., The Waterworks Act of 1915; the Minerals Act of 1917; and the public Health Act off 1917) an post-colonial periods (e.g., the Oil in Navigable Waters Act, 1968; the petroleum Act, 1969; Land use Act, 1978; the National Effluent limitation Regulation 1991; Waste Management Regulation, 1991; the ELA decree, No. 86 of 1992; Water Resources decree, No. 101 of 1993, among others) (Table 5). Water management practices during these periods were more disjointed in approach (responding to emergencies), with a number of vague and unrealistic assumptions (e.g. Land use Act of 1978). More so, implementation mechanisms were stronger and realistic at pre-independent and colonial periods and very weak at post-colonial period. This probably was so given the fact that the colonial masters were more sensitive to water-based and water-washed problems than the natives. Although the colonial masters attempted to put down some statutes to guide water management, the influence of customary laws were and are still very strong among the natives both at pre-colonial and post-colonial periods. In northern Nigerian for instance, the strength of the customary laws in water resources management was, and is still very influential as most management modes are community centred through negotiation, consensus and customary rights of access. This situation in the south is almost at the same angle of influential customary system, though at a lesser scale than the northern region (because of contrasting hydrological extremes between the two regions). As a matter of fact, where there is any conflict between the statuary rights and customary rights the former would, in principle, take precedence.

Generally and with regard to domestic water issues, statutory rights of management are embedded in the Land use Act of 1978 and the Water resources decree of 1993. While the water resources decree vests all the waters within the territorial borders of Nigeria, the Land use Acts give right for groundwater exploitation within a given tenure boundary. The division between surface and groundwater has important implications with regard to the issue of ownership of water. In constitutional terms, surface water is primarily considered river water. Here there is a partial riparian perspective to rights to water which is:'.... essentially one of rights to the waters of a flowing river inhering in, or as claimed by different users located alongside (or in the vicinity) of that river. This can arise at the level of households, farms, communities, villages or towns, but occurs in a more marked form at the level of political or administrative units within a country' (lyer, 2003). Jurisdiction over dispute is vested in the government; explicitly, Federal government in relation to inter-state disputes and implicitly, the state in the case of intra-state rivers.

In contrast, ownership of groundwater is linked to land ownership which, although subject to governmental control and regulation, is difficult to regulate legally, given obscure regulatory legislation and multiplicity of uses and responsible agencies. This leads to inequities of various kinds, given that land ownership is in most cases skewed (Joshi, 2004). The linking of water and land rights led to a situation of unmitigated tapping of groundwater by individuals with means and capacities to do so, especially in the urban areas (Akpabio, 2006). This has important implications bordering on the health of the aquifer and the quality of water people drink.

The authority of the Minister for Waste Resources to control groundwater use includes the power to define the time, places and manner in which water may be taken or used; to fix the amount that may be taken in times of shortage; to prohibit the taking or use of water for health reason; to regulate the construction and operation of boreholes; and finally to revoke a right to use or take water in the public interest. In the discharge of its statutory duties, the Ministry is required to make proper provision for adequate supplies of suitable water for domestic, and domestic use; the watering of animals, irrigation, agricultural purposes as well as the generation of hydro-electric energy for navigation, fisheries and recreation. As defined in the Water Resources Decree, the term "domestic use" means the use of water for drinking, washing, bathing, cooling, gardening, or for any other domestic purpose in any residential premises utilized for non-profit motives; the term "non-domestic use" means the use of water from any waterworks for profit or gain.; while the term "public use" refers to any domestic or agricultural use from any waterworks provided through any fountain, standpipe, valve, tap or appliance used by the public.

The Federal Ministry of Water Resources (FMWR) is the main government agency responsible for the management and control of water resources in Nigeria. An institutional framework comprising the River Basin Authorities and the National Water Resources Institute supports it. The general mission of the Federal Ministry is to harness underground and surface water resources for irrigation, recreation, navigation, hydropower generation, and water supply for domestic and industrial use. Its specific duties include the formulation of national water resources policies, the implementation of a water resources master plan for the development of dams, irrigation and drainage, water supply, soil erosion and flood control as well as hydrological and hydro geological activities. In addition, the Federal Ministry is required to develop and support irrigated agriculture and reduce the nation's dependence on rain fed agriculture, and promote and sustain national water security by minimizing unexpected and undesirable shortfalls in domestic food production and agro-based raw materials caused by the vagaries of weather. As part of its responsibilities, the Federal Ministry is expected to co-ordinate the development and utilization of water resources for irrigation and water supply: develop a centralized water supply and sanitation monitoring and evaluation programme for the country; develop 
programmes and policies toward surface water storage schemes; and develop guiding principles for dam construction nation-wide. Special attention is to be paid to water resource development in the rural areas in connection with which the Federal Ministry is directed to formulate and support a national rural water supply programme with a national on-farm storage programme emphasizing the involvement of local communities. Twelve River Basin Authorities assist the Federal Ministry of Water Resources. However, the authorities are prohibited from acquiring or leasing land or taking on acquisition of any existing project without the knowledge and consent of the State Governments in their area of operation. Although the authorities are authorized to make byelaws for the management of irrigation schemes and regulating the use of water, such byelaws are unenforceable unless confirmed by National Council of Ministers. The government also created the National Water Resources Institute to promote and develop training programmes and courses in water resources and to advise the Government on water resources needs and priorities.

Currently, Nigeria's National Water Resources Policy aims at optimizing the use of its water resources for present generation to live without compromising the existence of future generations and to ensure the development and management of Water resources in an integrated manner. It has been developed to set directions for separate sub sector policies like Dams and Reservoir Operations, Irrigation and Drainage, etc. Nigeria is now pursuing the above policy initiatives through the implementation of relevant programmes in various parts of the country. These include: National water supply and sanitation policy, urban water sector reforms, the presidential water initiatives and integrated water resources management, among others.

\section{Emerging Issues and Concluding Remarks}

Water governance in Nigeria has not matured from theory to practice. This is because the fundamental institutional pillars of what should drive effective governance in the water sector is appallingly weak and, in most cases, mom-responsive to the general needs of the citizenry. For instance, analyses in the paper have shown that water related legislations and regulations are very shallow. This has to do with the reactive management approaches of relevant bodies, which see legislations and regulations in the water sector emerging out of emergencies and pressures. Over the years of Nigeria's existence, there has never been any systematically and proactively evolved water management plan that reflect the realities of the country's ecological configurations as well as the needs of the citizenry. Even the few lists of regulations/legislations (Table 5) that are available at the federal level must have arisen by executive decisions and directives without the participatory inputs of the citizens. Except the few legislations put down by the colonial master (the water works Acts 1915; the Minerals Act of 1917; and the Public Health Act of 1917), all others were the products of military fiats and pronouncements (Akpabio, 2007). The very first attempt at making a semblance of governance practice in the water sector came when the idea of using the river basins as units of organizing water management in emerged in 1976. Though the idea represented a significant realization of the need for effective holistic water governance, the mere fact that such decisions were handed down from the top without the active involvement of the citizens makes it a weak imitation of what should constitute effective water governance. Many scholars have passed a 'failing' judgement on the river basin concept in Nigeria (Mitchell, 1999; Salau, 1986 \& 1990; Akpabio, et al, 2007). The most pronounced cases of such failure are the antagonistic relationship between basin management authorities and host communities (Akpabio, 2007). Throughout the discussions in the paper, it is important to note that the federal government of Nigeria seems to be leading and most influential actor in the water governance of Nigeria. As a federal arrangement, it is important note that states and local authorities' involvement in water governance matter, is weak, with relationship assuming a very subservient or unilateral arrangements. The federating states depend on the centre for initiative, even if such initiatives do not match well with the ecological circumstances of such states. Using the Cross River Basin (CRB) as a case, Akpabio (2007) and Akpabio et al (2007) have variously criticized the idea of imposing a uniform water management plans and mandates on all the eleven reviver basin development units in Nigeria without regard to the circumstances of the ecological system in the respective basin. As such ecological sensitivities are lacking at policy levels, it logically implies that implementation at proactive levels cannot succeed.

In conclusion, this paper argues that there is absolutely no effective water governance practice in Nigeria. This, we know. What is not calculated, however, is the uncertainty surrounding the water future of the country and the citizen, given the current realities of bad and uncoordinated practices as well as access and supply problems. 


\section{References}

Akpabio, E. M. (2006). Institutional Arrangements for Integrated Water Resources Management in the Cross River Basin, Nigeria. Unpublished PhD Dissertation. Department of Geography \& Regional Planning, University of Uyo, Nigeria.

Akpabio, E. M., Watson, N. M., Ite, U. E. and Ukpong, I. E. (2007) Integrated water resources management in the Cross River Basin, Nigeria International Journal of Water Resources Development 23:4:691-708.

Akpabio, E. M. (2007a). Nigeria's Water Law: how is it translated in the Cross River Basin? International Journal of Regulation and Governance. Vol 7, No. 2:157-184.

Akpabio, E. M. (2007b) Assessing integrated water resources management in Nigeria: Insights and lessons from irrigated projects of the Cross River Basin. Water Policy 9:2,149-168.

Ayibotele, N. B. (1992). The World's Water: Assessing the Resources. Paper Presented at the International Conference on Water and the Environment: Development Issues for the 21st Century, January 26-31. Dublin, Ireland.

Ayoade, J. O. and B. L. Oyebande (1993): Water Resources. In J. S. Oguntoyinbo, O. O. Areola, M. Filami (eds). A Geography of Nigerian Development. Heinemann Educational Books (Nig.) Ltd.

Allan, T. (2001). The Middle East Water Question. Hydro politics and the Global Economy. London: I. B. Tauris \& Co.

Bahattacharyya, A., Parker, E. \& Raffiee, K. (1994). An Examination of the Effect of Ownership on the Relative Efficiency of Public and Private Water Utilities. Land Economics 70 (2): 197-209.

Byrnes, P., Grosskopf, S. \& Hayes, K. (1986). Efficiency and Ownership: Further Evidence. Review of Economics and Statistics, 65:337341.

Broca, S. And Oram, P. (1991). Study on the Location of the Poor. Paper Perpared for the Technical Advisory Committee of the Consultative Group on International Agriculture Research. Washington, D. C. International Food Policy Research Institute.

Buds, J. \& McGranahan, G. (2003). Are Debates on Water Privatization Missing the Points? Experiences from Africa, Asia and Latin America. Environment and Urbanization 15 (2): 87-113

Castro, J. E. (2007). Water Governance in the Twentieth-First Century. Ambiente \& Sociedade. V. X, n. 2 p.97-118. Jul. Dez.

Commission on Global Governance (1995). Our Global Neighbourhood. Oxford University Press: 2

Cosgrove, W. J. (2003). Water Security and Peace. A synthesis of Studies Prepared under the PCCP-Water for peace Process (An UNESCO-Green Cross International Initiative). Technical Documents in Hydrology, PC-CP Series, n.29. paris: UNESCO, 2003. Cited in Casto, J. E. (2007-Op cit).

FAO (1998). Special Report: Floods Cause Extensive Crop Damage in Several Parts of Asia Global Information and Early Warning System on Food and Agriculture. 27 August 1998. Rome: FAO

FAO (2000). Nigeria. Irrigation Sub-sector Study. Main Text and Annexes. Investment Centre Report No. 00/076 CP-NIR

FGN (2000). Water Supply and Sanitation Interim Strategy Note. Nov. 2000.

Finger, M., L. Tamiotti and J. Allouche (2006). The Multi-Governance of Water, Four Case Studies. State University of Newyork Press.

Frank, T. (2004). Water Governance: What is the Consensus? Presented at ESRC Seminar, the Water Consensus-Identifying the Gaps Bradford Centre for International Development. www.bradford.ac.uk/acad/bcid/seminar/water/seminar/pepers/

Frank, T. \& Cleaver, F. D. (2007). Water Governance and Poverty: a Framework for Analysis. Progress in Development Studies 7 (4) 291-306

Gleick, P. H. (1996). Basic Water Requirements for Human Activities. Meeting Basic Needs. Water International 21 (2).

Grosh, B. (1991). Public Enterprises in Kenya: What Works, What Doesn't and Why? Lynne Reinner Published, Boulder \& London

Gupta, D. B. (1992). The Importance of Water Resources for Urban Socio-economic Development. Paper Presented at the International Conference on Water and the Environment, 26 to 31, January. Dublin, Ireland.

Hukka, J. J. \& T. S. Katko (2003). Water Privatization Revisited: Panacea or Pancake? IRC Occasional Paper Series 33. Delft: International Water and Sanitation Centre (IRC).

IYER, R. R. (2003). Water Perspectives, issues, concerns. Sage Publications New Delhi, India

Joshi, D. (2004). Secure water-whither poverty? Livelihoods in the DRA approaches: A case study of water supply programme in India. Water policy Report No.4. Overseas Development Institute, London

K' Akumu, O. A. (2006). Privatization Model for Water Enterprise in Kenya. Water Policy (8): 539-557

Kjellen, M. \& G. McGranahan (1997). Comprehensive Assessment of the Freshwater Resources of the World. Urban Water-Towards Health and Sustainability, Stockholm Environmental Institute, Stockholm.

Kooiman, J. (ed) (1993). Modern Governance. New Government-Society Interactions. Sage Publications.

Lambert, D., Dichev, D. \& Raffiee, K. (1993). Ownership and Sources of Inefficiency in the Provision of Water Services. Water Resources Research 29 (6): 1573-1578.

Marvin, S. \& Laurie, N. (1999). An Emerging Logic of Urban Water management Cochabamba, Bolivia Urban Studies 36 (2): $341-357$.

Mitchell, B. (1990). Introduction, In: Integrated Water Management: International Experiences and Perspectives, pp.1-21, B. Mitchell (ed.) Belhaven, London.

Nellis, J. (1994). Is Privatization Necessary? FPD Note No.7. The World Bank Public Policy for the Private Sector. Washington DC, May.

Renzetti, S. \& Dupont, D. (2003). Ownership and performance of Water Utilities. Greener Management International, 42:9-19.

Revaga, C., S, Murray, J. Abramovitz and A. Hammond (1998). Watersheds of the World: Ecological Value and Vulnerability. Washington DC. World Resources Institute/Worldwatch Institute

Regers, P.\& Hall, A. (2003) Effective Water Governance. Global Water Partnership, TEC Background Papers, No.7. 
Rosegrant, M. W. (1997). Water Resources in the Twenty-first Century: Challenges and Implication for Action. Food, Agriculture, and the Environment. Discussion Paper. No. 20. Washington, DC.IFPRI

Rosegrant, M. W., C. Ringler and R. V. Gerpacio (1997). Water and Land Resources and Global Food Supply. Paper Presented at the 23rd Conference of the International Association of Agricultural Economists, August, 1997, Sacramento, California.

Ryan, P. (2004). Scaling-up: a Literature Review. International Resource Centre. www.irc.ni/content/download/14863/198001filescalingup it rev

Saal, D. \& Parker, D. (2001). Productivity and Price Performance in the Privatized Water and Sewerage Companies of England and Wales, Journal of Regulatory Economics 20.

Salau, A. T. (1986). River Basin Planning as a strategy for rural development in Nigeria Journal of Rural Studies, 32(4), pp. 321-35

Salau, A. T. (1990). "Integrated Water Management: The Nigeria Experience". Integrated Water Management: International Experiences and Perspectives, P. 188-202. Bruce Mitchell (ed.). London and New York: Belhaven Press.

Schulpen, L. \& Gibbon, P. (2001). Private Sector Development Policies, Practices and Problems. CDR Working Paper. Centre for Development Research, Copenhagen, May.

Sharma, M. (1996). African Water Resources: Challenges and Opportunities for Sustainable Development. Technical Paper (Africa Region). No. 331. Washington, D. C. World Bank.

Shiklomanov, I. (1993). World Fresh Water Resources. In: P. Gleick (ed). Water Crisis: A Guide to the World's Fresh Water Resources. Op. Cit.

Smil, V. And M. Yushi (1998). The Economic Costs of China's Environmental Degradation. Project on Environmental Scarcities, State Capacity and Civil Violence. Cambridge, Mass; American Academy of Arts and Sciences.

Teka, G. E. (1997). Water Supply in Ethiopia. Addis Ababa, Ethiopia: University Press.

The Independence (2006). Armed Forces are put on Standby to Tackle Threat of Wars over Water. London, 28 February.

Thomas, C. And P. Clegg (1998). Water and the Current Development Orthodoxy: World Bank Policy under the Spotlight. In Vajpeyi, D. K. Water Resource Management-a Comparative Perspective (pp19-32). Preager Publishers, CT 06881.

UN-HABITAT (2003). Water and Sanitation in the World's Cities Local Action for Goals. Earthscan Publication Ltd, London.

UN-Water/Africa (2003). Africa Water Vision 2025: Equitable and Sustainable Use of Water for Social economic Development.

Van Ginkel, H. (2001). Discourse of the United Nations Under Secretary General at the Stockholm Water Symposium, 13 August. Quoted in the Financial Times, 14 August 2001, p.6. Cited in Castro (2007)

Water Profit of Nigeria. Food and Agriculture Organization.

Webb, P. \& M. Isandarani (1998). Water Insecurity and the Poor. Number 12 Issues and Research Needs. ZEF Discussion Papers on Development Policy, Bonn. October, 1998. Centre for Development Research, Bonn. Germany.

WHO (1995). World Health Report. Geneva. World Health Organization.

WHO (1996). Water and Sanitation. Fact Sheet No. 112. Geneva. WHO.

WHO (1997). UNICEF Agree on Joint Strategy to Improve Water Supply and Strengthen Local Health System. Press Release. No. 43. MAY 23. Geneva.

WHO (1998). World Health Report. Life in the 21st Century, A Vision for All. Geneva. WHO.

WHO/UNICEF (2002). Cited in Nikson, A. \& R. Franneys (2001). Tapping the Market-Can Private Enterprise Supply Water to the Poor?.. Id21 Insights Issue \#37. www.d21.org/insights/insights37/insights-iss37-editorial.html

WRI (1996). World Resources 1996/97. the Urban Environment. Washington DC World Resources Institute.

Yoffe, S. et al (2004). Geography of International Water Conflict and Cooperation: Data Sets and Applications. Water Resources 40(5):112. Cited in Castro (2007). Water Governance in the Twentieth-First Century. Ambiente \& Sociedade. V. x., n. 2 p.97-118. Jul. Dez 
